AGRO EKONOMI, Vol 30, Issue 2, December 2019, Page.95-109

DOI : http://doi.org/10.22146/ae.46439

ISSN 0215-8787 (print), ISSN 2541-1616 (online)

Available at https://jurnal.ugm.ac.id/jae/

\title{
CHARACTERISTICS OF YOUNG HORTICULTURAL FARMERS IN MALANG REGENCY
}

\author{
Eri Yusnita Arvianti ${ }^{1}$, Masyhuri ${ }^{2}$, Lestari Rahayu Waluyati ${ }^{2}$, Dwijono Hadi Daryanto ${ }^{2}$ \\ ${ }^{1}$ Doctoral Student in Agricultural Economics, Faculty of Agriculture, \\ Universitas Gadjah Mada \\ ${ }^{2}$ Departement of Socioeconomics, Faculty of Agriculture, Universitas Gadjah Mada \\ Jl. Flora No. 1 Bulaksumur, Yogyakarta \\ e-mail: yusnitaarvianti@yahoo.co.id
}

Submitted : 16 June 2019 ; Revised : 12 August 2019 ; Accepted: 9 September 2019

\begin{abstract}
The horticulture subsector occupies a strategic position in the development of Indonesia's agriculture sector. Farmers have an important role in developing agriculture and promoting the agricultural sector in Indonesia. Therefore this paper aims (1) to find out the distribution of characteristics of young farmers in Malang Regency, (2) to understand the managerial capacity and empowerment of young farmers in horticultural agriculture in Malang Regency. This research was conducted in five villages in Malang Regency in 2018. These villages were Codo Village, Dampit Village, Punten Village, Gempol Village, and Ngantru Village. The sample was determined by census with a sample size of 195. Descriptive method was used as the analytical method. Data were obtained using interviews through questionnaires. The results shows that the characteristics of young horticultural farmers in Malang Regency were mostly in their 30s and men. The level of education of young horticultural farmers was low and on average had 9 years of agricultural experience with low land ownership. An intensive policy is needed for young farmers in terms of land ownership. Most farmers have used cellphones or gadgets to carry out agricultural transactions. Most young horticultural farmers in Malang Regency already have good managerial capacity, but in terms of empowerment is still not optimal. The government and farmer groups need to increase their role in supporting the agriculture of young horticultural farmers to be more developed so that young farmers in Malang Regency do not leave their jobs in the agricultural sector.
\end{abstract}

Keywords : farmers' characteristics, horticulture, young farmers

Arvianti, E.Y, Masyhuri, \& Waluyati, L.R., \& Dwijono H.D. (2019) Characteristics of Young Horticultural Farmers in Malang Regency. Agro Ekonomi 30(2), 95-109.

\section{INTRODUCTION}

Human resourcesare oneimportant aspect having a major role in sustainable agricultural development. The quality and willingness of human resources to develop and make innovations are essential factors contributing to the success of sustainable agricultural development (Susilowati, 2016). Productive human resources in the agricultural sector are still very limited. In 2018 there were only 10.52 percent 
of young farmers from the total number of farmers. The age of farmers is still dominated by farmers aged 40 years and over (BPS, 2018). This situation has been around for a long time, even now the number of young farmers is decreasing. Age of farmers who are now classified as old age causes an increase in agricultural productivity is not optimal and the quality of agricultural products is difficult to improve. From year to year the number of farmers is also decreasing. Agricultural development is faced with a dilemma that is difficult to solve quickly. One side of agricultural land is increasingly narrow along with the use of agricultural land for industrial and residential activities. The limited land ownership within farmers also causes young farmers to be not interested in doing farm business. In addition, the low quality of land results low productivity and decreases the income of young farmers. Limited capital also leads them to look more for work in other sectors.

Many people think that being a farmer is an unprofitable and non prestigious job, so many young people from rural areas prefer to work in town or abroad because such jobs are more promising. Therefore, younger generation who is willing to work in agricultural sector is declining, resulting in low farmer regeneration. The young generation, who should contribute to agricultural development by investing their money into this sector, tend to add to the urban population and create more challenges to rural agricultural development (Felicia et al., 2016). On the other hand, the number of young people working in non-agricultural sector is increasing. In addition, the fact that the number of older farmers is more dominant than young farmers and a decline in the interest of younger generation in working in agricultural sector can be found not only in Asia, but also in other countries throughout the world, including in the European countries and Canada (Uchiyama, 2014). On the other hand, an increase in the number of population is followed by an increase in food needs. An increase in income will also be followed by an increase in the need for food quality and variety. Such diversity requires agricultural product processing by skillful farmers. Therefore it is important to understand the characteristics of farmers, especially young farmers.

Empirical studies of the characteristics of young farmers in horticultural commodities have not been widely conducted because until now there are only a few studies on young farmers. In fact, many studies only discuss the characteristics of farmers in general. Here are some studies on the characteristics of farmers: a study conducted by Iriyani 
and Nugrahani (2017) with an objective to provide information about the characteristics of peri-urban vegetable farmers in Surabaya. The novelty of this study is that this study enhances the characteristics of young farmers working in horticulture in Malang, while also looking at characteristics in terms of management capacity and empowerment that are different from previous research. The contribution of the researchers in the research conducted is that this character analysis will be one way to motivate themselves, especially young farmers to remain consistent and interested in agriculture, the horticulture sector is very promising if it is taken seriously. Therefore, the objectives of this study are to (1) find out about the distribution of young farmers' characteristics in Malang Regency, (2) find out about the managerial capacity and empowerment of young farmers in horticultural farming in Malang Regency.

\section{METHODS}

This study used a survey method. Five villages in Malang Regency, namely Codo Village, Dampit Village, Punten Village, Gempol Village, and Ngantru Village were investigated. The choice of location in Malang Regency was based on the number of agricultural business households where it accounts for 328,369 farm households, the highest in East Java. In addition, Malang Regency is one of the horticulture centers (BPS, 2015). While five villages were chosen since each village has a large number of young horticultural farmers. The sample was chosen by census as many as 195 samples with details of 24 samples from Codo Village, 30 samples from Dampit Village, 63 samples from Punten Village, 37 samples from Gempol Village, and 41 samples from Ngantru Village.

In the first objective regarding the distribution of characteristics of young farmers in Malang Regency, descriptive methods were used, namely research methods focusing on solving problems in the present. Information from the literature and data were collected, analyzed, and elaborated. Descriptive research aims to provide a systematic picture of the facts and characteristics of an object or subject precisely (Nazir, 2005). In the second objective to find out managerial capacity and empowerment of young farmers in horticultural agriculture in Malang Regency, the method used was also applied using descriptive methods by looking at the results of the survey in the field by giving the scores contained in the questionnaire. Indicators of measurement of empowerment were seen from the existence of counseling, development of systems and facilities for horticultural agricultural products, 
ease of access to information and knowledge, and institutional institutions of farmers. While managerial capacity indicators were measured through operational planning at the time and input of horticulture crop production and post-harvest handling before planting horticulture crops, regulating management activities in labor operations, using input and post-harvest handling, and evaluating horticultural or post-harvest crop production, time, and input used. Furthermore, the results of young farmers' responses from each indicator statement are added. The sum result was then converted into an index from 0 to 100 which was calculated by means (Puspitawati et al., 2018)

Index $=\frac{\text { Score obtained }- \text { minimum score }}{\text { Maximum score }- \text { minimum score }} \times 100$

Index results are grouped into 3 categories: low (0-50\%), (51-75\%), and high (> 75\%). In this study, the primary data were obtained from the field and secondary data collected from the Indonesian Central Bureau of Statistics (www.bps.go.id). Literature was obtained from previous studies, books, and other references.

\section{RESULTS AND DISCUSSION}

Characteristics of Young Horticultural Farmers in Malang Regency

Youth is a group with age ranged from 18 years and above until the initial age of 40 years. The group is the most productive, idealist, mature thinking and wins to be the driving force of development (Silva et al., 2009). According to Minister of Agriculture Regulation No. 7 of 2013, the Youth Generation of Agriculture is a Young Generation of Agriculture that has been approved for a maximum of 35 years. Some countries use different age limits. The study conducted by Katchova and Ahern (2014) used a 35-year age limit for young farmers. The Australian Government uses a 40 year limit as a youth farmer (Murphy, 2012). Based on the above references, in this study used the age limit of young farmers from 18 years to 40 years.

\section{Age and Sex}

An increasing number of old farmers influences the agricultural demographics in the future. Age will bring effects in terms of agricultural innovation, physical abilities, opinions about the sustainability of efficient agriculture, and environmental concern (organic agriculture) (Zagata and Sutherland, 2015). Figure 1 presents the identity of young horticultural farmers by age and sex in Malang Regency in 2018. The identity of young horticultural farmers by age was divided into 5 categories and by sex is divided into male and female population as seen in Figure 1. 
Figure 1. shows that $31.28 \%$ of young horticultural farmers was between 32-36 years old. At productive age, farmers still had strong energy so they can perform their jobs optimally. Productive age also allowed horticultural farmers to work optimally, producing optimal agricultural production. The fact that there is a large number of productive young horticultural farmers shows that young farmers have a high level of participation to work. In addition, farmers at productive age are more progressive towards new innovations and more courageous in making decisions (Iriyani and Nugrahani, 2017). Farming performed by farmers with productive age can be optimal due to their physical ability (Asih, 2009). Research conducted by Hamilton et al. (2015) in the United Kingdom explains that farmers in the age group of 35 to 45 years showed higher levels of productivity, profitability and investment consistently. In addition, young farmers consistently show a higher level of involvement in organic farming. Research conducted by Saiyut et al. (2017) in Thailand, indicating that farmers aged 60 years and over can increase the technical inefficiency of agricultural businesses, while farmers aged 15-59 can reduce technical inefficiencies in agricultural production. In terms of sex, $96.41 \%$ of horticultural farmers in Malang Regency were male, while the remaining $3.59 \%$ were female, so among the farm households in Malang Regency in 2018, male was more responsible for household needs. According to Cavicchioli et al. (2018) hereditary agricultural work has more opportunities to be passed on by firstborn boys by sex and birth order because there is still a family and normative belief that male lineages can represent sources of economic inefficiency in agricultural management. Intrinsic factors that exist in individual

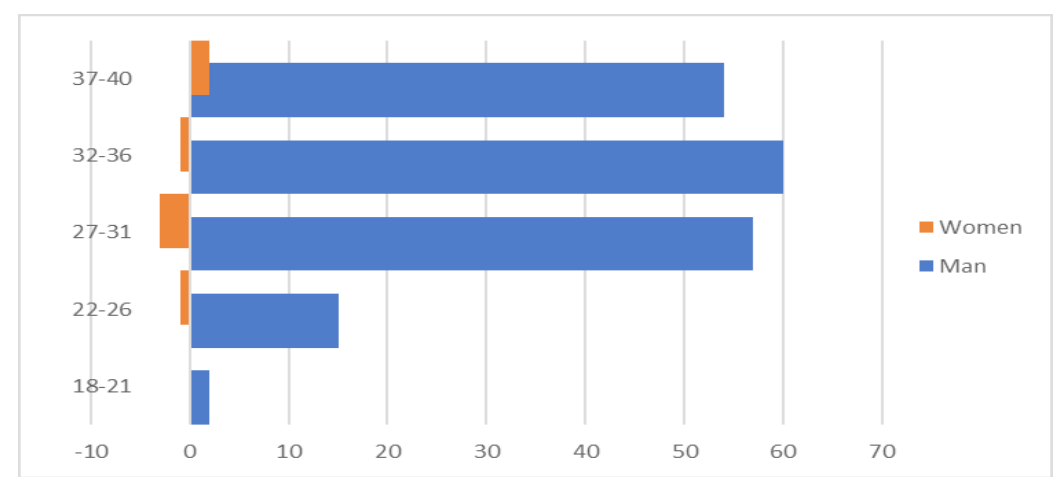

Figure 1. Identity of Young Horticultural Farmers in Malang Regency Based on Age and Gender in 2018

Source: Primary Data Analysis (2018) 
characteristics influence the interest of farmers.

\section{Level of Education}

Formal education in this study is the level of education of respondents in following the learning process in formal schools. The level of formal education pursued by young farmers reflects the insights and knowledge possessed by farmers. Formal education aims to create quality human beings, both in terms of science and technology and improve good morals (Adawiyah et. al, 2017). Level of education affects young farmers in terms of how they accept and adopt technology as well as how they gain information related to agriculture (Iriyani and Nugrahani, 2017).

From table 1 it can be seen that $44.10 \%$ of young horticultural farmers were graduated from junior high school (7-9 years), 30.77\% graduated from senior high school (10-12 years), $21.54 \%$ graduated from elementary school (1-6 years), and the remaining 3.59\% were university graduates. The primary data shows that the majority of horticultural farmers in Malang Regency did not have good level of education because in average the education of young horticultural farmers in Malang Regency was nine years, meaning that they were junior high school graduates. The low level of education makes it difficult for farmers to accept a variety of new information and technologies, so farming is carried out conventionally based on their farm experience. Farmers who are highly educated are relatively easier to adopt an innovation and usually they will always look for information about new innovations to develop their business (Mukti et al., 2017).

From table 1 it can be seen that $44.10 \%$ of young horticultural farmer graduated from junior high school (7-9 years), 30.77\% graduated from senior high school (10-12 years), $21.54 \%$ graduated from elementary school (1-6 years), and the remaining 3.59\% were university graduates. The primary data shows that the majority of horticultural farmers in Malang Regency did not have good level of education because in average the education of young horticultural farmers in Malang Regency was nine years, meaning that they were junior high school graduates. The low level of education makes it difficult for farmers to accept a variety of new information and technologies, so farming is carried out conventionally based on their farm experience. Farmers who are highly educated are relatively easier to adopt an innovation and usually they will always look for information about new innovations to develop their business (Mukti et al., 2017). 
Table 1. Identity of Young Horticultural farmers in Malang Regency by Level of Education in 2018

\begin{tabular}{clcc}
\hline No. & \multicolumn{1}{c}{$\begin{array}{c}\text { Level of Education } \\
\text { (year) }\end{array}$} & $\begin{array}{c}\text { Number } \\
\text { (people) }\end{array}$ & $\begin{array}{c}\text { Percentage } \\
(\%)\end{array}$ \\
\hline 1 & 0 & 0 & 0.00 \\
2 & $1-6$ & 42 & 21.54 \\
3 & $7-9$ & 86 & 44.10 \\
4 & $10-12$ & 60 & 30.77 \\
5 & $>12$ & 7 & 3.59 \\
\hline Total & & 195 & 100.00 \\
\hline
\end{tabular}

Source: Primary Data Analysis (2018)

\section{Farm Experiences}

Farm experience is the experience of farmers in carrying out their farming. The longer the farm experience, the better the knowledge of farmers to overcome any farming challenges. Farm experience may influence farmers in making decisions related to the development of their farming. Figure 2 presents the identity of young horticultural farmers in Malang Regency by level of farm experience.

Figure 2. shows that $34.36 \%$ of young horticultural farmers in Malang Regency had 6-10 years of farm experiences, while the average farm experience of all the young horticultural farmers was 9 years. Only $20.00 \%$ of young farmers had more than 15 years of farm experiences. This shows that young horticultural farmers in Malang Regency already had enough experience although $29.23 \%$ of farmers were still new to horticultural farming. The length of farm experience indicates that horticultural farming is something that has not been done for a long time. Based on the results of the study, farmers considered the horticulture commodities in Malang Regency profitable because $36.41 \%$ of horticultural farmers in Malang Regency had carried out horticultural farming for more than 10 years. Considering the length of farmers doing horticultural farming, it can be said that horticultural farming is still profitable until now.

\section{Land Ownership}

Narrow land for farming may become an obstacle for intensively implementing a farming system and may cause farmers to be less able to apply agricultural technology and commercial farm managemen. Land access is also one of the important indicators that encourage young people to take part in agriculture (Rovny, 2016). For most youth, the lack of access to land, capital and other inputs limit their desire 


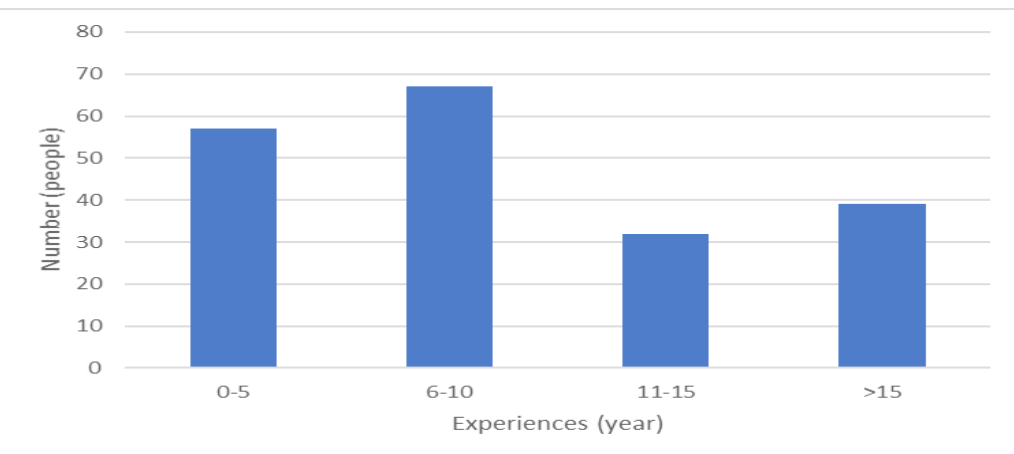

Figure 2. Histogram of The Identity of Young Horticultural Farmers in Malang Regency by Level of Farm Experience.

Source: Primary Data Analysis (2018)

to cultivate the world of agriculture. Youth who own land also have better perceptions and expectations of their farming business (Pujiriyani et al., 2016). Table 2. presents the land ownership of young horticultural farmers in Malang Regency in 2018.

Table 2. Horticultural Farm Land Ownership in Malang Regency in 2018.

\begin{tabular}{lrr}
\hline $\begin{array}{c}\text { Land Area } \\
\left(\mathrm{m}^{2}\right)\end{array}$ & $\begin{array}{r}\text { Number } \\
(\text { People })\end{array}$ & $\begin{array}{r}\text { Percentage } \\
(\%)\end{array}$ \\
\hline$<1.000$ & 45 & 23.08 \\
$1.000-5.000$ & 120 & 61.54 \\
$6.000-10.000$ & 25 & 12.82 \\
$>10.000$ & 5 & 2.56 \\
\hline Total & 195 & 100.00 \\
\hline
\end{tabular}

Source: Primary Data Analysis (2018)

Table 2 . shows that $61.54 \%$ of young horticultural farmers in Malang Regency had land ownership of 1000-500 $\mathrm{m}^{2}$. $23.08 \%$ of them had land ownership less than $1000 \mathrm{~m}^{2}$ and $2.56 \%$ of them had land ownership larger than $10,000 \mathrm{~m}^{2}$ or 1 ha.
In average, young horticultural farmers in Malang Regency had a land area of 2,942 $\mathrm{m}^{2}$. Seen from the land ownership of young horticultural farmers in Malang Regency, it can be said that the land areas of these young horticultural farmers in Malang Regency were relatively narrow. The low level of land ownership was due to the fact that some young farmers continue their parents' farming business with narrow land. In fact, the benefit of owning narrow land is better monitoring of production facilities, sufficient labor, small capital, and lower risks (Iriyani and Nugrahani, 2017). However, narrow agricultural land can reduce farming efficiency resulting in decreased profits so young farmers prefer to switch professions to more profitable jobs. Therefore there is an incentive for young farmers in terms of land tenure, especially for young farmers who are able to show their achievements in agricultural business. In addition, land arrangements and implementation that 


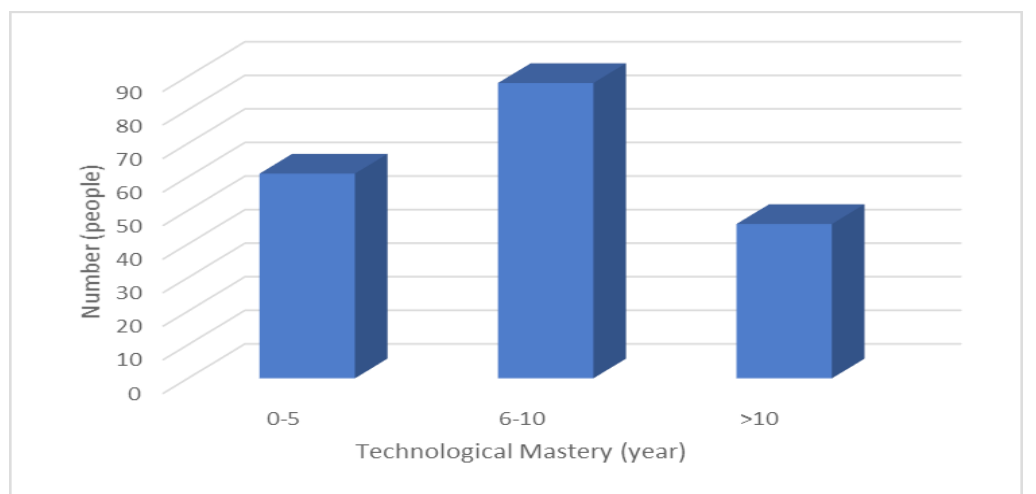

Figure 3. Histogram of The Technological Mastery of Young Horticultural Farmers in Malang Regency in 2018.

Source: Primary Data Analysis (2018)

are in accordance with regional spatial planning are needed so that agriculture is not eroded by modernization.

\section{Technological Mastery}

Technological mastery is a form of competence that farmers should have. The technological mastery of young horticultural farmers in Malang Regency is in the form of the mastery of cellular communication to establish communication related to production and marketing.

In average, farmers already used technology (mobile phone) for 9 years. $45.13 \%$ of young horticultural farmers in Malang Regency already used mobile phones for $6-10$ years, $31.28 \%$ of young farmers used mobile phones for 0-5 years, and $23.59 \%$ of them used mobile phones for more than 10 years. However, there were two farmers who did not have mobile phone. In the current digital era, the use of technology is growing rapidly so every individual is required to catch up with the development. Therefore, the majority of farmers have long used mobile phones and the use of such communication devices makes it easier for them to make transactions with their partners.

Managerial Capacity of Young Horticultural Farmers in Malang Regency

Managerial capacity was used to determine the ability of young horticultural farmers in Malang Regency in terms of applying management principles or functions which consist of planning, organizing, implementing, and evaluating. There were $56.84 \%$ of young horticultural farmers in Malang Regency who had good managerial capacity. This shows that the majority of young horticultural farmers in Malang Regency already had planning for horticultural 
farming. Most of these young farmers had recorded their farming, planned the use of production facilities prior to planting, planned the number of workers they needed to hire, planned the planting dates, made budget planning, used production facilities as recommended, and evaluated production results.

Young farmers in Malang Regency who have good managerial capacity are mostly between the ages of 32-36 years with average agricultural experience of 9 years and 9 years of education. At the age of 32-36 years, young farmers already have a mature mind to run their agriculture and are accompanied by long experiences. Unlike farmers in the age range of 18-21 years, they had low managerial capacity due to lack of experience. In addition, based on research in the field, 24 young farmers in Codo Village had low managerial capacity. Young farmers in the village did not recorded agriculture because their awareness of the importance of farming records is still low and do not know how. This could happen because in Codo Village, the empowerment of young farmers was still low. The lack of coordination between agricultural extension officers and young farmers in Codo Village was the cause of a lack of information and knowledge of farmers about managing agricultural businesses. Good managerial capacity can be influenced by the experience of young farmers who have long been cultivating in the horticulture sector so that farmers easily know the stages and what needs to be prepared before and the cultivation process. The high level of education of young farmers makes them think more in the long term. Farm records can be used to evaluate horticultural agriculture for further planting. In addition, the role of agricultural extension agents is also

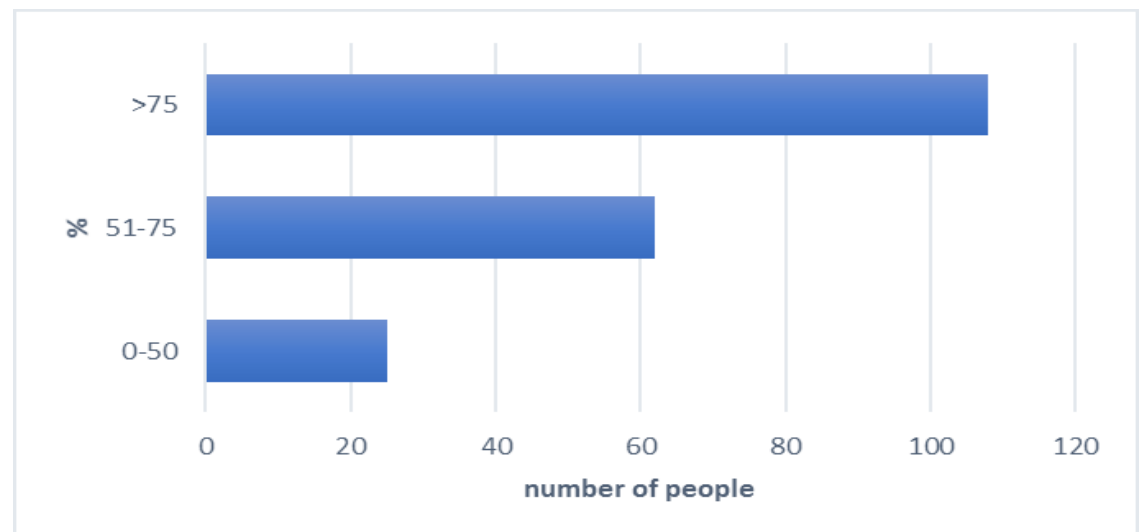

Figure 4. Histogram of The Managerial Capacity of Young Horticultural Farmers in Malang Regency in 2018.

Source: Primary Data Analysis (2018) 
important in relation to the distribution and dissemination of innovation and knowledge of horticultural agriculture.

\section{Empowerment of Young Horticultural Farmers in Malang Regency}

Empowerment of young horticultural farmers is an effort to improve the capacity to perform horticultural farming in terms of technological innovation, increased access to information, capital assistance, and development of human resources. Figure 5 presents a histogram of the empowerment of young horticultural farmers in Malang Regency in 2018. There were $22.05 \%$ of young horticultural farmers in Malang Regency who perceived that the active role of government agencies or farmer groups was adequate and $43.60 \%$ of them perceived that the role of government agencies and farmer groups was good, especially in supporting their horticultural farming, for example the government through extension programs, provision of knowledge and training and assistance from PPL or farmer groups through regular meetings. However, $34.35 \%$ of these farmers did not perceive any role of the government or farmer groups in supporting their horticultural farming. This way, the empowerment of young farmers in Malang Regency can be seen to be not optimal because not all farmers received the same facilities or support for their farming, especially young farmers in Codo Village. Farmers in the village felt that the role of extension agents is still low. This was due to the the lack of awareness of young farmers in Malang Regency about the importance of direct coordination or collaboration with extension agents. Many young farmers were active, but did not have intensive relations or communication with extension agents so that their knowledge and innovation were still low. According to Nugroho and Waluyati (2018) the existence of incentives such as training will increasingly attract many young people to move in the agricultural sector. In addition, the support of modern machine tools makes the younger generation interested in agriculture because of the ease in managing commodities. Research conducted by Pardian et al. (2017) shows that the presence of training can provide perceptions and interest of young farmers on cultivation methods so that young farmers have the willingness to explore and cultivate their farm more. The government or farmer groups need to make new record of the young horticultural farmers in Malang Regency and list farmers who have not received the same facilities. According to May et al. (2019) the role of community has a 
significant effect on the willingness of young farmers to remain in agricultural sector.

Empowering young farmers through training is very important for farmers, especially for young people. In addition, young farmers have a high level of education. At this age and level of education, it is easier for farmers to receive information and apply adoption technology. Young farmers also prefer to use technology, for example applications needed on mobile phones about agriculture can improve farmers' performance.

Currently, the majority of the agricultural sector in Indonesia still uses traditional technology and technology adoption is still low, while in the industrial sector and technology services are already very advanced so that many young people are interested in working in the sector (Umunnakwe et al., 2014). Empowerment of farmers by the government is needed when farmers are productive.

\section{CONCLUSIONS AND SUGGESTION}

Most young horticultural farmers in Malang Regency have a level of education that is not yet high enough so that training and counseling is needed on technological innovation. Besides that the age of young farmers who are still productive makes them able to learn quickly. Young farmers have a long experience that shows that horticulture farming still provides economic benefits. Most farmers have used cellphones or gadgets to carry out their agricultural transactions, making it easier for them to make transactions with their partners. In addition, the average land ownership of young farmers is still low. There is an incentive policy for young farmers in terms of land ownership. Land titling activities need to be continued.

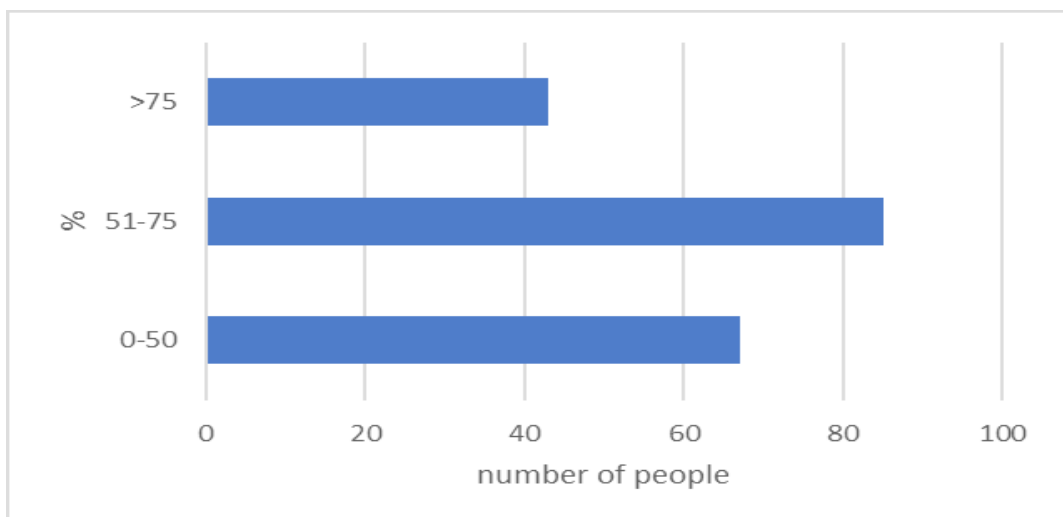

Figure 5. Histogram of The Empowerment of Young Horticultural Farmers in Malang Regency in 2018.

Source: Primary Data Analysis (2018) 
Especially for young farmers who are able to show their achievements in the agricultural business. Land management and utilization are also needed in accordance with spatial planning so as not to overlap with other sectors. There needs to be an appropriate mapping so that agricultural land is not eroded by modernization.

Most young horticultural farmers in Malang Regency already have good managerial capacity because they have planned, recorded, implemented good cultivation recommendations, and evaluated their agricultural output. However, empowerment carried out by government institutions and farmer groups is still not optimal and equal because not all farmers get benefits or facilities provided by extension agencies and farmer groups. Extension workers and young farmers must work together in developing agricultural businesses. It requires proper cooperation that is able to make young farmers aware in order to develop the agricultural business. The application of new technology is also very necessary to support the agricultural business. It is hoped that with the support of government institutions and farmer groups, the young farmers in Malang Regency will not leave the agricultural sector.

\section{ACKNOWLEDGE}

I would like to thank to Universitas Gadjah Mada, Unitri Malang, and Budi DN Sholarship.

\section{REFERENCES}

Adawiyah, C. R., Sumardjo, \& Mulyani, E. S. (2017). Faktor-faktor yang Mempengaruhi Peran Komunikasi Kelompok Tani dalam Adopsi Inovasi Teknologi Upaya Khusus (Padi, Jagung, dan Kedelai) di Jawa Timur. Jurnal Agro Ekonomi, 35(2), 151-170.

Asih, D. N. (2009). Analisis Karakteristik dan Tingkat Pendapatan Usahatani Bawang Merah di Sulawesi Tengah. Jurnal Agroland, 16(1), 53-59.

BPS. (2015). Statistik Hortikultura Provinsi Jawa Timur. Jawa Timur: Badan Pusat Statistik Provinsi Jawa Timur.

BPS. (2018). Hasil Survei Pertanian Antar Sensus (SUTAS) 2018. Jakarta.

Cavicchioli, D., Bertoni, D., \& Pretolani, R. (2018). Farm Succession At A Crossroads: The Interaction Among Farm Characteristics, Labour Market Conditions, and Gender And Birth Order Effects. Journal of Rural Studies, 61(2018), 
73-83. https://doi.org/10.1016/j. jrurstud.2018.06.002

Felicia, W. I., Emmanuel, F. O., \& Olaseinde, A. T. (2016). Assessing The Future Of Agriculture in The Hands of Rural Youth in Oriade Local Government Area of Osun State , Nigeria. International Journal of Agricultural Extension, 04(02), 105-110.

Hamilton, W., Bosworth, G., \& Ruto, E. (2015). Entrepreneurial Younger Farmers and The "Young Farmer Problem" in England. Agriculture \& Forestry, 61(4), 6169. https://doi.org/10.17707/ AgricultForest.61.4.05

Iriyani, D., \& Nugrahani, P. (2017). Karakteristik Petani Sayuran Periurban Kota Surabaya. Prosiding Seminar Nasionsl Tahunan Matematika, Sains, Dan Teknologi Universitas Terbuka Convention Center, 105-118.

Katchova, A. L., \& Ahern, M. (2014). Farmland Ownership and Leasing: Implications for Young and Beginning Farmers (No. 486). Kentucky.

Mahudin, F. N., \& Shabahati, I. (2017). Krisis Petani Muda Masa Depan. Kinerja Logistik Indonesia Hingga Kini, II(21), 3-8.
May, D., Arancibia, S., Behrendt, K., \& Adams, J. (2019). Preventing Young Farmers from Leaving The Farm : Investigating The Farm Effctiveness of The Young Farmer Payment Using A Behavioural Approach. Land Use Policy, 82(2019), 317327. https://doi.org/10.1016/j. landusepol.2018.12.019

Mukti, G. W., Andriani, R., Kusumo, B., \& Qanti, S. R. (2017). Perilaku Sukses Petani Muda Wirausaha Lulusan Fakultas Pertanian Universitas Padjadjaran. Jurnal Agribisnis TErpadu, 10(2), 221-234.

Murphy, D. (2012). Young Farmer Finance Schemes. Australia.

Nazir, M. (2005). Metode Penelitian. Bogor: Ghalia Indonesia.

Nugroho, A. D., \& Waluyati, L. R. (2018). Upaya Memikat Generasi Muda Bekerja pada Sektor Pertanian di Daerah Istimewa Yogyakarta Efforts of Engage Youth Generation to Working on Agricultural Sector in Yogyakarta Province. Jurnal Ilmu Pemerintahan Dan Sosial Politik UMA, 6(1), 76-95.

Pardian, P., Rasmikayati, E., Djuwendah, E., \& Saefudin, B. R. (2017). Persepsi dan Minat Petani Muda Dalam Budidaya Sayuran Swiss Chard 
Organik. Jurnal Aplikasi Ipteks Untuk Masyarakat, 6(3), 163-166.

Pujiriyani, D. W., Suharyono, S., Hayat, I., \& Azzahra, F. (2016). Sampai Kapan Pemuda Bertahan di Pedesaan? Kepemilikan Lahan dan Pilihan Pemuda untuk Menjadi Petani. Bhumi, 2(2), 209-226.

Puspitawati, H., Herawati, T., \& Sarma, M. (2018). Reliabilitas dan Validitas Indikator Ketahanan Keluarga di Indonesia. Jurnal Kependudukan Indonesia, 13(1), 1-14.

Rovny, P. (2016). The Anaysis of Farm Population With Respect to Young Farmers in The European Union. Procedia Social and Behavioral Sciences, 220(2016), 391-398. https://doi.org/10.1016/j. sbspro.2016.05.513

Saiyut, P., Bunyasiri, I., \& Sirisupluxana, P. (2017). Kasetsart Journal of Social Sciences The Impact of Age Structure on Technical Efficiency in Thai Agriculture. Kasetsart Journal of Social Sciences, хxx(2017), 1-7. https://doi.org/10.1016/j. kjss.2017.12.015

Silva, J. L. D., Shaffril, H. A. M., Uli, J., \& Samah, B. A. (2009). A Review of Contract Farming and Factors that Impinge Youths Acceptance to Contract Farming. European Journal of Social Sciences, 11(2), 328-338.

Susilowati, S. H. (2016). Femomena Penuaan Petani dan Berkurangnya Tenaga Kerja Muda serta Omplikasinya bagi Kebijakan Pembangunan Pertanian. Forum Penelitian Agro Ekonomi, 34(1), 35-55.

Uchiyama, T. (2014). Recent Trends in Young People's Entry into Farming in Japan: An International Perspective. In Enhanced Entry of Young Generation into Farming (pp. 1-14). Jeonju: FFTC-RDA International Seminar.

Umunnakwe, V. C., Pyasi, V. K., \& Pande, A. K. (2014). Factors Influencing Involvement in Agricultural Livelihood Activities Among Rural Youth in Jabalpur District of. International Journal of Agricultural Policy and Research, 2(August), 288-295.

Zagata, L., \& Sutherland, L. (2015). Deconstructing The 'Young Farmer Problem in Europe': Towards a Research Agenda. Journal of Rural Studies, 38(2015), 3951. https://doi.org/10.1016/j. jrurstud.2015.01.003 